\title{
Perspectives
}

\section{Eugenics and Sterilization in the Heartland}

\section{Michael L. Wehmeyer}

On May 2, 2002, Mark Warner, governor of the Commonwealth of Virginia, apologized for "Virginia's participation in eugenics," which he categorized as a "shameful effort in which state government never should have been involved" "“Virginia Apologizes," 2002). Governor Warner's apology was issued on the 75th anniversary of the United States Supreme Court's decision in Buck v. Bell (1927), which "opened the floodgates" (Smith \& Polloway, 1993) for the wholesale sterilization of people with epilepsy or who were then classified as feeble-minded. It was also the anniversary of Justice Oliver Wendell Holmes' now infamous statement that "three generations of imbeciles are enough." Fittingly, Virginia also dedicated a historical marker to the memory of Carrie Buck, who became the first person to be forcibly sterilized under Virginia's 1924 law on sterilization, upheld by the 1927 Supreme Court decision.

Virginia has received the lion's share of publicity with regard to human sterilization, in part due to the infamy of the Buck v. Bell case and its impact on the subsequent rate of sterilizations; in part because so many sterilizations were performed in that state after Buck v. Bell; and in part because the voices in our field that have most persistently and eloquently reminded us not to forget this portion of our past have often come from Virginia (Smith, 1994, 1995; Smith \& Nelson, 1989; Smith \& Polloway, 1993). It is worth noting, however, that in considering the appropriate response to the occasion of Virginia's apology, the stain of sterilization is not limited to the Commonwealth of Virginia but permeates the fabric of our country. There are, undoubtedly, many more apologies owed. Virginia was neither first to the sterilization scene nor, perhaps, the most enthusiastic of its enactors (although Kevles, 1995, noted that by the end of the 1940s, Virginia was second nationally in the total number of sterilizations performed, accounting for roughly one seventh of all sterilizations in the country up to that time).
The first state sterilization law was passed by the Indiana legislature on March 9, 1907, providing for the "prevention of the procreation of "confirmed criminals, idiots, imbeciles, and rapists"' (Landman, 1932, p. 55). On May 11, 1921, however, the Supreme Court of Indiana declared this statute unconstitutional. A second law was passed March 27, 1927, that was ruled constitutional. As of January 1,1928 , the state of Indiana had sterilized 120 persons involuntarily (Gosney \& Popenoe, 1929), although Gosney and Popenoe noted that "six or seven hundred males were sterilized in Indiana, for eugenic reasons, between 1899 and the adoption of the law in 1907" (p. 185).

Virginia, by the same date, had sterilized only 17 persons. When Virginia passed its sterilization law on March 20, 1924, it was the 21st state to pass such legislation. Washington, California, Connecticut, Nevada, Iowa, New Jersey, New York, North Dakota, Kansas, Michigan, Wisconsin, Nebraska, Oregon, South Dakota, New Hampshire, North Carolina, Alabama, Montana, and Delaware all enacted involuntary sterilization laws prior to Virginia. If Buck $v$. Bell led to the mass sterilization of people with mental and developmental disabilities in the United States, the foundations for that explosion were set well before it became the test case for sterilization (Smith \& Nelson, 1989).

Virginia's and Indiana's use of sterilization prior to Buck v. Bell pales in comparison to that of California, where a statute was passed on April 26, 1909, calling for the sterilization of "inmates of state hospitals, of feeble-minded children in the California Home for the same, and of convicts in the state prisons" (Landman, 1932, p. 58). A second, stronger, statute was passed on June 13, 1913, and went into effect in California on August 10 of that same year, providing for the "sterilization of the insane and feeble-minded inmates of state hospitals and of convicts and idiots in state institutions" (Landman, 1932, p. 58). The 1913 statute 
was amended in June of 1917, and then a third statute was passed on July 31, 1917, which

gives the authority to the board of trustees, on the recommendation of the superintendent, a clinical psychologist with a Ph.D. degree and a physician, to sterilize committed feeble-minded, chronic manic and demented people, with or without their consent, before discharging them (Landman, 1932, p. 59).

This latter statute was included in an act establishing the Pacific Colony for the Feeble-Minded and Epileptic in California.

Landman (1932) noted that "these combined statutes are functioning satisfactorily," as evidenced by the fact that "as many as seven thousand five hundred forty-eight operations have been performed," estimated to be half of all sterilizations performed in the country up to that point (p. 59). Functioning "satisfactorily" indeed; by January 1, 1928, California had sterilized 5,820 people with intellectual disabilities. The Human Betterment Foundation (1937), reporting the number of sterilizations up to January 1, 1938, indicated that California had performed 12,180 involuntary sterilizations by that date, followed by Virginia $(2,916)$, Kansas (1,915), Michigan (1,815), Minnesota $(1,459)$, and Oregon $(1,218)$.

California's enthusiasm for sterilization came from many corners, but at least one factor explaining this enthusiasm was the efforts of Ezra Gosney and Paul Popenoe of the Human Betterment Foundation. This foundation was established and existed solely to promote the use of eugenic sterilization for purposes of race and human betterment.

Paul Bowman Popenoe was at the forefront of the eugenics movement and, as secretary of the Human Betterment Foundation, became a force in the sterilization movement. Educated at Stanford (though not a Stanford graduate), he was a pupil of Stanford University President David Starr Jordan, a leading eugenicist who was chairman of the American Breeders Association's Committee on Eugenics and a member (along with Lewis Terman) of the Human Betterment Foundation's advisory board. In 1913, Popenoe was appointed editor of the Journal of Heredity. In 1926, he became secretary of the Human Betterment Foundation, which published numerous tracts and texts promoting eugenic sterilization. In addition, Popenoe was the co-author of Applied Eugenics (Popenoe \& Johnson, 1918), a widely used text. His whole-hearted promotion of sterilization, exceeded in enthusiasm only, perhaps, by Harry Hamilton Laughlin of the Eugenics Records Office (who developed the model sterilization law on which the 1924 Virginia law was based), had long-ranging impact. It is clear that, like Laughlin's work in drafting model sterilization legislation, Popenoe's efforts influenced many, including the German eugenics program, which included the forced sterilization of more than 32,000 Germans considered to be "feeble-minded" (Biesold, 1988). Kevles (1995) noted that German eugenicists said that they "owed a great debt to the American precedence, including the report of Gosney and Popenoe on the California program" (p. 114). Laughlin's impact was so strong on German eugenics that he was awarded an honorary doctorate from a German university in recognition of his efforts.

Popenoe provided the link from California to my home state, Kansas, which was active in sterilizing people with mental retardation both before and after Buck v. Bell. In Gosney's and Popenoe's Sterilization for Human Betterment (1929), Kansas is second in total sterilizations performed (647 by January 1,1928$)$. By the time of the 1938 tract issued by the Human Betterment Foundation, Kansas had slipped to third behind Virginia, though totaling nearly 2,000 sterilizations. Popenoe was born in 1888 in Topeka, Kansas. His father, Fred, had moved with his family to Topeka when he was 6 years old, and eventually he became secretary to Kansas Governor John P. St. John, one of the leading crusaders against alcohol in Kansas. (Governor St. John served from 1879-1883 and then was Prohibition Candidate for President of the United States in 1884.) Fred Popenoe eventually was a highly visible citizen of the Kansas capital city, becoming owner and publisher of the Topeka Daily Capital newspaper.

As in many states, the sterilization of people with mental retardation in Kansas commenced well before it was legal. A wire story on April 3, 2000, in the Wichita Eagle newspaper, noted that

The effort to sterilize the unfit in Kansas began in 1894 with F. Hoyt Pilcher, then superintendent of Winfield's Kansas State Asylum for Idiotic and Imbecile Youth. By 1895, Pilcher had developed a reputation as a trailblazer. The Winfield Courier reported: "The unsexing of one hundred and fifty of these inmates - male and female - was an innovation that received the endorsement of the entire medical profession of the world, and the plaudits of right thinking people everywhere. (Tanner, 2000)

Thus, portending the 1907 land rush from Kansas into the Indian territory of Oklahoma, Kansas rushed into sterilization with reckless abandon. Pilcher's enthusiasm for sterilization, however, exceeded the appetites of the citizens of Kansas, and 
by 1899 , he was forced to resign his position as superintendent. Pilcher's legacy was longer lasting, however, than his superintendency. At the 34th annual meeting of the American Association for the Study of the Feebleminded in 1910, F. C. Cave, then superintendent of the Kansas Training School in Winfield, reported on the results of asexualization operations performed on 58 inmates of the institution. These sterilizations had occurred under Pilcher's watch, and Cave was upbeat about the success of the effort, noting that "these operations prevent the begetting of defective offspring and also limit lewdness and vice" (p. 124). He closed his positive report on sterilization by warning that "it is time some drastic action were taken to stem the ever increasing tide of weak-minded individuals who are demanding more and more room in our charitable institutions by their increase" (p. 125).

It was at this same meeting that Henry Herbert Goddard of the Vineland New Jersey Training School (and popularizer of the "menace" of the feeble-minded) presented a "new" classification system that included the classification of "moron" for persons who tested between 8 and 12 years on the increasingly popular Binet intelligence test. In addition, Charles B. Davenport (1910), director of the Eugenics Records Office, presented a paper on the application of Mendel's law to human heredity, urging that the facts on "reproduction of imbeciles be placed in the hands of each state legislature to the end that at least female imbeciles be in general prevented from reproduction by restraint during the reproduction period (say from 15 to 45 ) or by sterilization" (p. 95).

Indeed, the earliest indication of a swing toward support for involuntary sterilization on the part of the superintendents who comprised what would become the American Association on Mental Retardation has links to Superintendent Pilcher. In his 1897 presidential address to the membership at the 21st annual meeting in Ontario, Canada, Martin Barr posed the question as to "How best to render the imbecile harmless to himself and to the world?" and, noting the potential benefit of "asexualization" laws over laws governing marriage of people with epilepsy or mental retardation, cited the "example of Pilcher of Kansas who had the moral courage and scientific conviction to perform operations to 'unsex' 11 boys" despite the fact that "Pilcher was censured by the newspapers" (Barr, 1897).

On March 14, 1913, Kansas, well after Pilcher's reign, passed a law stating that forced sterilization was acceptable if "the mental or physical condition of any inmate would be improved ... or that procreation by such inmates would be likely to result in defective or feeble-minded children." On October 6, 1928, the Supreme Court in Kansas held that a later version of the Kansas sterilization law (passed March 13, 1917) was constitutional. Landman (1932) observed that "The Buck v. Bell decision mandated May 2, 1927 has definitely altered the judicial opinion of this country in favor of this kind of legislation" (p. 69).

I was prompted to write this perspective as a result of two recent events. The first was the aforementioned Associated Press article reporting Governor Warner's apology. The second was a comment I heard recently. While spending the day examining the archives of the noted eugenicist Charles Davenport, I approached the research librarian with a request to photocopy some correspondence between Davenport and a Kansan. This research librarian literally spends day after day reading and cataloging the writing of Charles Davenport, the man most closely aligned with the rise of the eugenics movement in America and with the promulgation of negative eugenics worldwide. Despite this intimate knowledge of the eugenics movement, this librarian commented that he did not think there was much of a connection with eugenics in Kansas. Although I am sure that this archivist knew that Harry Laughlin was from the neighboring state of Missouri and, perhaps if pressed, could recall that Charles Davenport's wife (who carried on much of his work as he traveled) was a native Kansan, I also suspect that his relative surprise at a Kansas connection was sincere. As such, it is perhaps an opportune time, with the Virginia apology, for an examination of, or more likely an acknowledgement of, the actions of eugenicists in other states.

Is such a self-examination important? I turn to a passage that Gunnar Dybwad (2000) wrote in the epilogue to a text on mental retardation in the 21 st century:

Thus I have a vivid memory of conditions that to most readers will only be historical facts which they have read. I saw first hand the dismal conditions in the overcrowded institutions which originated in good intentions, to give asylum and protection and quickly became warehouses to offer society protection from the so-called "mental defectives." I saw in the late 1930s, overcrowding with all its dire consequences was the major problem. In Letchworth Village, considered to be one of the "better" New York State institutions at that time, I found a dormitory with one hundred beds and 125 children in those beds. 
Today there are revisionist historians who seek to minimize the horror of the Nazi holocaust, or even to deny its existence. Survivors keep the memory alive, and work to reconstruct a written record for posterity chanting "never again!" We are confronted with our own holocaust in the area of intellectual disability. The actual holocaust story is kept alive because of a strong belief that this is necessary to prevent a repetition in years to come. Likewise, the institutional horrors must be kept alive by eyewitnesses, as it is in Burton Blatt's trail blazing Christmas in Purgatory (1966), which he published at great risk to his professional reputation. It must not be forgotten, it can not be erased from our professional history. (pp. 432-433)

If this is true for institutionalization, it must be even more so for the tragedy of the involuntary, forced sterilization of more than 50,000 Americans whose sole crime was to have, or be claimed to have, an intellectual impairment. Apologies not only acknowledge an injustice, but also help ensure that such events are not erased from our history or consciousness. Let us hope that Virginia's apology is only the first.

\section{References}

Barr, M. W. (1897). President's address. Journal of Psycho-Asthenics, 2(1), 4.

Biesold, H. (1988). Crying hands: Eugenics and deaf people in Nazi Germany. Washington, DC: Gullaudet University Press.

Buck v. Bell, 274 U.S. 200, 47 S. Ct., 584 (1927).

Cave, F. C. (1910). Report of sterilization in the Kansas State Home for Feeble-Minded. Journal of Psycho-Asthenics, 15, 123-125.

Davenport, C. B. (1910). Application of Mendel's law to human heredity. Journal of Psycho-Asthenics, 15, 94.

Dybwad, G. (2000). Mental retardation in the 21st century. In M. L. Wehmeyer \& J. R. Patton (Eds.), Mental retardation in the 21st century (pp. 431-433). Austin, TX: Pro-Ed.

Gosney, E. S., \& Popenoe, P. B. (1929). Sterilization for human betterment: A summary of results of 6,000 operations in California, 1909-1929. Pasadena, CA: Human Betterment Foundation.

Human Betterment Foundation. (1937). Human sterilization today. Retrieved May 5, 2002, from
http://lcweb2.loc.gov/cgi-bin/query/D?rbpebib: 2:./temp/ ammem_CvyM

Human Betterment Foundation. (1938). Report to the Board of Trustees of the Human Betterment Foundation for the year ending February 8, 1938. Retrieved May 5, 2002, from http:// lcweb2.loc.gov/cgi-bin/query/D?rbpebib:1:./ temp/ ammem_CvyM

Kevles, D. J. (1995). In the name of eugenics: Genetics and the uses of human heredity. Cambridge: Harvard University Press.

Landman, J. H. (1932). Human sterilization: The history of the sexual sterilization movement. New York: MacMillan.

Popenoe, P., \& Johnson, R. H. (1918). Applied eugenics. New York: Macmillan.

Smith, J. D. (1994). Reflections on mental retardation and eugenics, old and new: Mensa and the human genome project. Mental Retardation, $32,234-238$.

Smith, J. D. (1995). The bell curve and Carrie Buck: Eugenics revisited. Mental Retardation, 33, 60-61.

Smith, J. D., \& Nelson, K. R. (1989). The sterilization of Carrie Buck. Far Hills, NJ: New Horizon Press.

Smith, J. D., \& Polloway, E. A. (1993). Institutionalization, involuntary sterilization, and mental retardation: Profiles from the history of the practice. Mental Retardation, 31, 208-214.

Tanner, B. (2000, April 3). Eugenics not Kansas' proudest moment. Wichita Eagle, p. B1.

Virginia apologizes for sterilizations. (2002, May 3). The Kansas City Star, p. A4.

My thanks to J. David Smith for his thoughtful consideration of this perspective and his helpful comments.

\footnotetext{
Author:

Michael L. Wehmeyer, PhD, Associate Professor, Department of Special Education; Director, Kansas University Center on Developmental Disabilities; and Associate Director, Beach Center on Disability, Haworth Hall, 1200 Sunnyside Ave., Rm. 3136, The University of Kansas, Lawrence, KS 13244. 2280. E-mail: wehmeyer@ku.edu
} 